Check for updates

Cite this: Chem. Sci., 2019, 10, 501

๑ All publication charges for this article have been paid for by the Royal Society of Chemistry

\title{
Colloidal tectonics for tandem synergistic Pickering interfacial catalysis: oxidative cleavage of cyclohexene oxide into adipic acid $\uparrow$
}

\author{
Bingyu Yang, ${ }^{a}$ Loïc Leclercq, (D) *a Véronique Schmitt, ${ }^{\text {b }}$ Marc Pera-Titus (D) *c \\ and Véronique Nardello-Rataj (D) *a
}

Supramolecular preorganization and interfacial recognition can provide useful architectures for colloidal building. To this aim, a novel approach, based on colloidal tectonics involving two surface-active particles containing both recognition and catalytic sites, has been developed for controlling the formation and the properties of Pickering emulsions. This was illustrated by the combination of dodecyltrimethylammonium phosphotungstate nanoparticles, $\left[\mathrm{C}_{12}\right]_{3}\left[\mathrm{PW}_{12} \mathrm{O}_{40}\right]$, and silica particles functionalized with alkyl and sulfonic acid groups, $\left[\mathrm{C}_{n} / \mathrm{SO}_{3} \mathrm{H}\right] \mathrm{aSiO}_{2}$. The interfacial self-assembly occurs by the penetration of the alkyl chains of $\left[\mathrm{C}_{n} / \mathrm{SO}_{3} \mathrm{H}\right] \mathrm{aSiO}_{2}$ into the $\left[\mathrm{C}_{12}\right]_{3}\left[\mathrm{PW}_{12} \mathrm{O}_{40}\right]$ supramolecular porous structure constituted of polar and apolar regions. The emulsions were used as a non-nitric acid route for adipic acid synthesis from the onepot oxidative cleavage of cyclohexene oxide with aqueous $\mathrm{H}_{2} \mathrm{O}_{2}$. The catalytic performance was significantly boosted due to the synergistic interactions between the particles.

Received 27th July 2018

Accepted 13th October 2018

DOI: $10.1039 / \mathrm{c} 8 \mathrm{sc} 03345 \mathrm{e}$

rsc.li/chemical-science

internal structure based on $\left[\mathrm{PW}_{12} \mathrm{O}_{40}\right]$ parallel planes separated by interdigitated surfactant chains, generating porous architectures constituted of polar and apolar regions where organic molecules can be accommodated..$^{2,6}$ In the presence of water and oil, they form very stable Pickering emulsions due to their bridging upon the release of some alkyl chains during oil penetration. ${ }^{6}$ More broadly, the surface interaction between molecules (tectons) can induce their self-assembly in reversible and predictable colloidal systems. ${ }^{7}$ This novel approach is here termed as "colloidal tectonics". ${ }^{8}$ The formation of $\left[\mathrm{C}_{12}\right]_{3}\left[\mathrm{PW}_{12} \mathrm{O}_{40}\right]$ NPs and their further use as an emulsifier strongly suggest that colloidal tectonics can be applied to the bottom-up design of emulsions driven by the interfacial self-assembly of NPs. ${ }^{8}$ To ensure the predictability and stability of the emulsions, "programming" of NPs is essential for controlling recognition events and their iterations (Fig. 1). ${ }^{8}$

It is well known that NP mixtures can stabilize Pickering emulsions. Unfortunately, this seems to be circumscribed to NPs with opposite charge, ${ }^{9-13}$ and different polarity ${ }^{14-17}$ or size. ${ }^{18-20}$ Alternatively, the colloidal tectonics approach offers a more general platform for building emulsions from $\left[\mathrm{C}_{12}\right]_{3}\left[\mathrm{PW}_{12} \mathrm{O}_{40}\right]$ NPs. Indeed, their interaction with silica NPs grafted with alkyl and sulfonic acid groups $\left(\left[\mathrm{C}_{n} / \mathrm{SO}_{3} \mathrm{H}\right] @ \mathrm{SiO}_{2}\right.$, $n=3,8$ and 18) should drive the concomitant self-assembly of both NPs driven by partial penetration of the alkyl chains of $\left[\mathrm{C}_{n} / \mathrm{SO}_{3} \mathrm{H}\right] @ \mathrm{SiO}_{2}$ into $\left[\mathrm{C}_{12}\right]_{3}\left[\mathrm{PW}_{12} \mathrm{O}_{40}\right]$ (Fig. 2). To illustrate the potential applications of this strategy, the self-assembled emulsions were evaluated for PIC tandem reactions being only attempted in few studies. ${ }^{21,22}$ Herein, we explored 


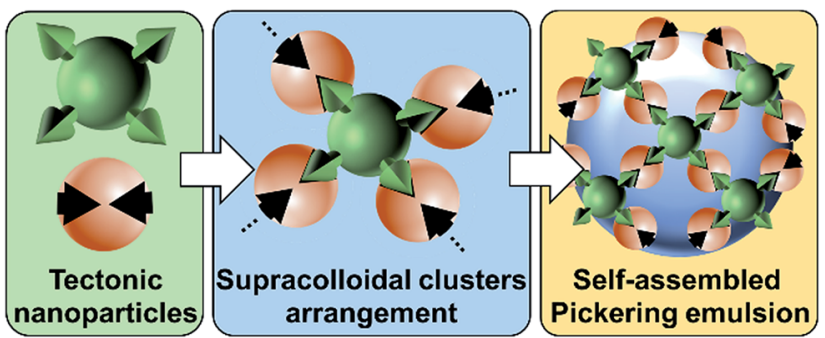

Fig. 1 Design of Pickering emulsions driven by the self-assembly of receptors and connectors (tectonic nanoparticles).

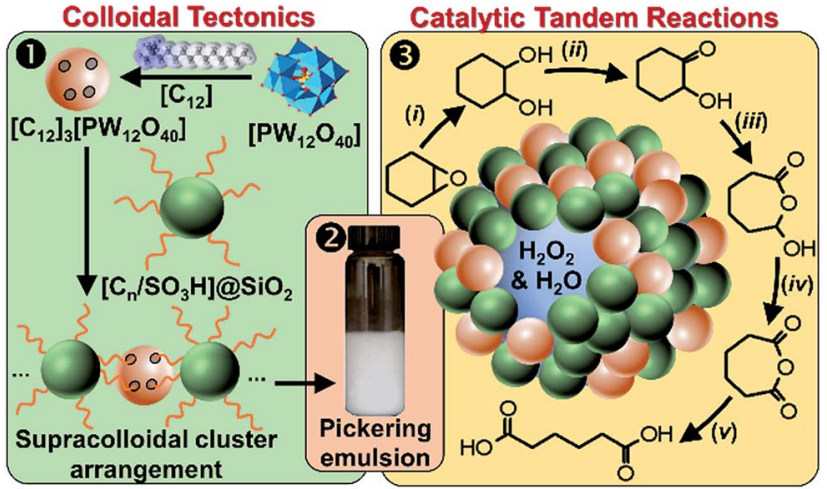

Fig. 2 From molecular tectonics to colloidal engineering of catalytic Pickering emulsions for adipic acid synthesis.

the synthesis of adipic acid (precursor of Nylon 6,6) from the one-pot oxidative cleavage of cyclohexene oxide with aqueous $\mathrm{H}_{2} \mathrm{O}_{2}$ as a non-nitric acid route. ${ }^{23}$ This eco-friendly synthesis requires the co-adsorption of $\left[\mathrm{C}_{n} / \mathrm{SO}_{3} \mathrm{H}\right] @ \mathrm{SiO}_{2}$ and $\left[\mathrm{C}_{12}\right]_{3}\left[\mathrm{PW}_{12} \mathrm{O}_{40}\right]$ catalyzing the hydrolysis (i and $\mathrm{v}$ ) and oxidation steps (ii-iv, see Fig. 2) of the overall reaction. ${ }^{24}$

\section{Results and discussion}

The NPs were prepared using protocols developed in previous studies. ${ }^{2,3}$ The $\left[\mathrm{C}_{12}\right]_{3}\left[\mathrm{PW}_{12} \mathrm{O}_{40}\right]$ NPs exhibit a spherical and monodisperse shape ( $\phi \approx 35 \mathrm{~nm}$, see ESI, Fig. S1 $\dagger$ ), negative $\zeta$-potential $(-36 \mathrm{mV})$ and a water contact angle $>90^{\circ}$ (Table 1). ${ }^{7}$ The $\left[\mathrm{C}_{n} / \mathrm{SO}_{3} \mathrm{H}\right] @ \mathrm{SiO}_{2}$ NPs also exhibit a spherical and monodisperse shape ( $\phi \approx 12-15 \mathrm{~nm}$, see ESI, Fig. S2-S5 $\dagger$ ), as well as a gradually negative $\zeta$-potential from -9 to $-42 \mathrm{mV}$ with chain lengths from $\mathrm{C}_{3}$ to $\mathrm{C}_{18}$. This behavior is closely related to the grafting degree and the $\mathrm{C}_{n}: \mathrm{SO}_{3} \mathrm{H}$ molar ratio. ${ }^{5}$ Increasing the chain length from $\mathrm{C}_{3}$ to $\mathrm{C}_{18}$ results in a lower grafting degree (from 58 to $32 \%$ ). As all $\left[\mathrm{C}_{n} / \mathrm{SO}_{3} \mathrm{H}\right] @ \mathrm{SiO}_{2} \mathrm{NPs}$ were prepared with the same nominal $\mathrm{C}_{n}$ : $\mathrm{SO}_{3} \mathrm{H}$ molar ratio (50/50), the $\mathrm{C}_{n}: \mathrm{SO}_{3} \mathrm{H}$ molar ratio after grafting can be associated with the accessibility of the reactants to the $\left[\mathrm{C}_{n} / \mathrm{SO}_{3} \mathrm{H}\right] @ \mathrm{SiO}_{2}$ surface, decreasing due to the steric hindrance and hydrophobicity of the grafted alkyl chains. ${ }^{5}$ In turn, both the grafting degree and the $\mathrm{C}_{n}: \mathrm{SO}_{3} \mathrm{H}$ molar ratio are linked to the acidity and hydrophilicity of the modified NPs: $\left[\mathrm{C}_{18} / \mathrm{SO}_{3} \mathrm{H}\right]<\left[\mathrm{C}_{8} / \mathrm{SO}_{3} \mathrm{H}\right]<\left[\mathrm{C}_{3} /\right.$ $\left.\mathrm{SO}_{3} \mathrm{H}\right] @ \mathrm{SiO}_{2}$. However, $\left[\mathrm{C}_{8} / \mathrm{SO}_{3} \mathrm{H}\right] @ \mathrm{SiO}_{2}$ and $\left[\mathrm{C}_{18} / \mathrm{SO}_{3} \mathrm{H}\right] @ \mathrm{SiO}_{2}$
Table 1 Main characteristics of the silica NPs used in this study

\begin{tabular}{lllll}
\hline & & \multicolumn{3}{l}{$\left[\mathrm{C}_{n} / \mathrm{SO}_{3} \mathrm{H}\right] @ \mathrm{SiO}_{2}$} \\
\cline { 4 - 5 } & {$\left[\mathrm{C}_{12}\right]_{3}\left[\mathrm{PW}_{12} \mathrm{O}_{40}\right]$} & $\mathrm{C}_{3}$ & $\mathrm{C}_{8}$ & $\mathrm{C}_{18}$ \\
\hline $\mathrm{DG}^{a, b}(\%)$ & - & 58 & 39 & 32 \\
$\mathrm{C}_{n}: \mathrm{SO}_{3} \mathrm{H}$ molar ratio & - & $64: 36$ & $73: 27$ & $82: 18$ \\
$\phi^{c}(\mathrm{~nm})$ & 35 & 15 & 12 & 14 \\
$\zeta^{d}(\mathrm{mV})$ & -36 & -9 & -38 & -42 \\
$\theta^{e}\left({ }^{\circ}\right)$ & 97 & 76 & 96 & 104 \\
Acidity $^{f}\left(\mathrm{mmol} \mathrm{H}^{+} / \mathrm{g}\right)$ & 0 & 1.45 & 0.70 & 0.38
\end{tabular}

${ }^{a}$ Grafting degree. ${ }^{b}$ Calculated from elemental and TG analyses. ${ }^{c}$ Diameter of NPs based on TEM (S.D. $\left.=15 \%\right) .{ }^{d}$ Determined for $1 \mathrm{wt} \%$ NPs in water (S.D. $=5 \%) .{ }^{e}$ Water contact angle measured on compressed NPs $($ S.D. $=2 \%) .{ }^{f}$ Calculated from elemental analysis and $\mathrm{pH}-\mathrm{metric}$ titration.

exhibit a water contact angle $>90^{\circ}$, reflecting poor wetting. The emulsifying capacity, defined as the ability of the NPs to emulsify various oils ( $n$-heptane, toluene or di- $n$-butyl ether) in water, is more prominent for the hydrophobic $\left[\mathrm{C}_{18} / \mathrm{SO}_{3} \mathrm{H}\right] @ \mathrm{SiO}_{2}$ NPs, generating water-in-oil (W/O) emulsions with all the solvents. Likewise, $\left[\mathrm{C}_{8} / \mathrm{SO}_{3} \mathrm{H}\right] @ \mathrm{SiO}_{2}$ gave $\mathrm{W} / \mathrm{O}$ emulsions with toluene, whereas the hydrophilic $\left[\mathrm{C}_{3} / \mathrm{SO}_{3} \mathrm{H}\right] @ \mathrm{SiO}_{2}$ did not stabilize any emulsion. Self-assembled $\left[\mathrm{C}_{12}\right]_{3}\left[\mathrm{PW}_{12} \mathrm{O}_{40}\right]$ NPs also stabilized $\mathrm{W} / \mathrm{O}$ emulsions with all the solvents. As only toluene could generate emulsions with $\left[\mathrm{C}_{8} / \mathrm{SO}_{3} \mathrm{H}\right] @ \mathrm{SiO}_{2},\left[\mathrm{C}_{18} / \mathrm{SO}_{3} \mathrm{H}\right]$ @ $\mathrm{SiO}_{2}$ and $\left[\mathrm{C}_{12}\right]_{3}\left[\mathrm{PW}_{12} \mathrm{O}_{40}\right]$ NPs, we conducted a complete physicochemical investigation on the emulsifying capacity of the different NPs for water/toluene systems.

The water/toluene emulsions $(1 / 1 \mathrm{v} / \mathrm{v})$ were prepared using $\left[\mathrm{C}_{n} / \mathrm{SO}_{3} \mathrm{H}\right] /\left[\mathrm{C}_{12}\right]_{3}\left[\mathrm{PW}_{12} \mathrm{O}_{40}\right]$ NP mixtures $(n=8$ or $18,3.6 \mathrm{wt} \%)$. The emulsions were visualized by optical microscopy to assess the evolution of the mean droplet diameter with the $\left[\mathrm{C}_{n} / \mathrm{SO}_{3} \mathrm{H}\right]$ @ $\mathrm{SiO}_{2}$ mass fraction, $\phi$ (Fig. 3). The mean droplet diameter decreases dramatically with $\phi$ until a plateau value around $\phi=$ 0.25 , reflecting an attractive (synergistic) interaction between both NPs. As the mean droplet diameter of the NP mixtures is equal to or less than that of single $\left[\mathrm{C}_{n} / \mathrm{SO}_{3} \mathrm{H}\right] @ \mathrm{SiO}_{2} \mathrm{NPs}$, the mixed interface formation seems to be governed by the silica NPs, being more "hydrophobic" than $\left[\mathrm{C}_{12}\right]_{3}\left[\mathrm{PW}_{12} \mathrm{O}_{40}\right]$ (Table 1). Unlike $\left[\mathrm{C}_{8} / \mathrm{SO}_{3} \mathrm{H}\right] @ \mathrm{SiO}_{2}$ and $\left[\mathrm{C}_{18} / \mathrm{SO}_{3} \mathrm{H}\right] @ \mathrm{SiO}_{2}$ for which stable $\mathrm{W} / \mathrm{O}$ emulsions are obtained for all mass fractions, no emulsion was observed with the hydrophilic $\left[\mathrm{C}_{3} / \mathrm{SO}_{3} \mathrm{H}\right] @ \mathrm{SiO}_{2}$. These results are very surprising because of the negative $\zeta$-potentials of $\left[\mathrm{C}_{12}\right]_{3}\left[\mathrm{PW}_{12} \mathrm{O}_{40}\right]$ and $\left[\mathrm{C}_{n} / \mathrm{SO}_{3} \mathrm{H}\right] @ \mathrm{SiO}_{2} \mathrm{NPs}$ (see $\zeta$-potentials in Table 1). Therefore, the repulsion between NPs should inevitably decrease the driving force of the assembly. Besides, the combined NPs exhibit even weaker $\zeta$-potentials compared to that of individual NPs. For instance, $\left[\mathrm{C}_{12}\right]_{3}\left[\mathrm{PW}_{12} \mathrm{O}_{40}\right]$ and $\left[\mathrm{C}_{18} / \mathrm{SO}_{3} \mathrm{H}\right] @ \mathrm{SiO}_{2} \mathrm{NPs}(-36$ and $-42 \mathrm{mV}$, respectively) give only $-17 \mathrm{mV}$ at $\phi=0.5$ (measured for $1 \mathrm{wt} \%$ NPs in water). In parallel, the aqueous conductivity is also greatly affected: $\left[\mathrm{C}_{12}\right]_{3}\left[\mathrm{PW}_{12} \mathrm{O}_{40}\right]$ and $\left[\mathrm{C}_{18} / \mathrm{SO}_{3} \mathrm{H}\right] @ \mathrm{SiO}_{2} \mathrm{NPs}$ (137 and $153 \mu \mathrm{S} \mathrm{cm}^{-1}$, respectively) give only $53 \mu \mathrm{S} \mathrm{cm}^{-1}$ at $\phi=0.5$. As the conductivity is related to the charge and size of the NPs, the formation of larger aggregates causes a decrease in the number of charge carriers and hence the conductivity decreases (i.e. 

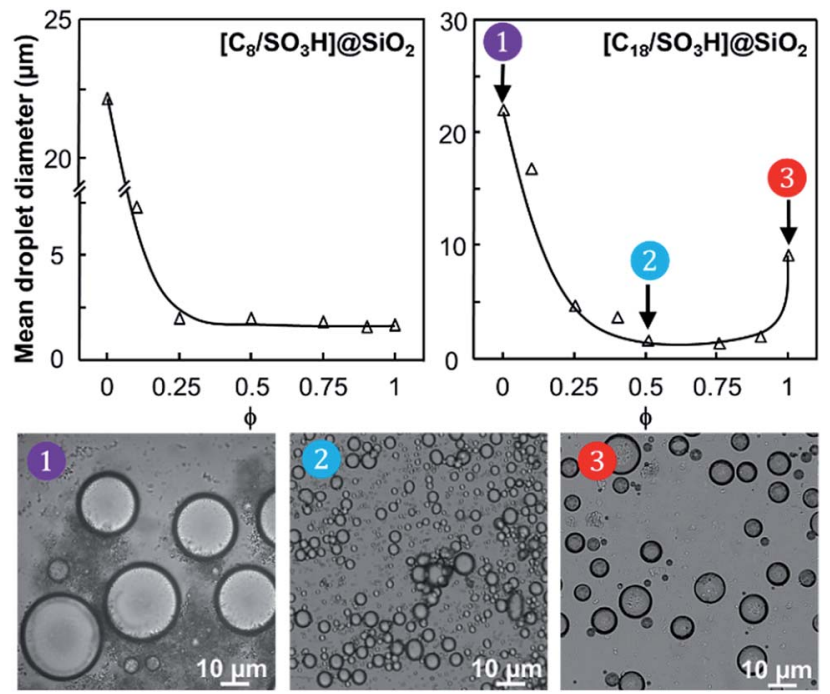

Fig. 3 Evolution of the droplet size (S.D. $=10 \%$ ) as a function of the $\left[\mathrm{C}_{n} / \mathrm{SO}_{3} \mathrm{H}\right] \mathrm{aSiO}_{2}$ mass fraction $(\phi)$ for water/toluene Pickering emulsions $(1 / 1 \mathrm{v} / \mathrm{v})$ stabilized by $\left[\mathrm{C}_{n} / \mathrm{SO}_{3} \mathrm{H}\right] \propto \mathrm{SiO}_{2}$ and $\left[\mathrm{C}_{12}\right]_{3}\left[\mathrm{PW}_{12} \mathrm{O}_{40}\right] \mathrm{NPs}$ (3.6 wt\%, $11500 \mathrm{rpm}$ ). The insets present the micrographs of the W/O emulsions.

there is self-assembly of $\left[\mathrm{C}_{12}\right]_{3}\left[\mathrm{PW}_{12} \mathrm{O}_{40}\right]$ and $\left[\mathrm{C}_{18} / \mathrm{SO}_{3} \mathrm{H}\right] @ \mathrm{SiO}_{2}$ NPs). It is clear that the stability of these aggregates results in the balance between attractive and repulsive forces. When two free negatively charged NPs approach each other, electrostatic repulsion becomes more significant. This repulsive energy can be overcome by van der Waals and depletion attractive forces between the largest $\left[\mathrm{C}_{12}\right]_{3}\left[\mathrm{PW}_{12} \mathrm{O}_{40}\right]$ and the smallest $\left[\mathrm{C}_{18} / \mathrm{SO}_{3} \mathrm{H}\right]$ @ $\mathrm{SiO}_{2} \mathrm{NPs}$ (35 and $14 \mathrm{~nm}$, respectively), leading to the formation of mixed aggregates. As the interaction energy is mainly governed by van der Waals forces between the alkyl chains of both NPs, this explains the tendency of hydrophobic NPs to agglomerate more easily as long as alkyl chains favour van der Waals interactions. For instance, the self-aggregation of $\left[\mathrm{C}_{12}\right]_{3}\left[\mathrm{PW}_{12} \mathrm{O}_{40}\right]$ and $\left[\mathrm{C}_{18} / \mathrm{SO}_{3} \mathrm{H}\right] @ \mathrm{SiO}_{2}$ NPs observed by TEM is shown in Fig. 4. As depicted in Fig. 4, the NPs are arranged into interconnected NP networks where the larger $\left[\mathrm{C}_{12}\right]_{3}\left[\mathrm{PW}_{12} \mathrm{O}_{40}\right]$ NPs are surrounded by the smallest $\left[\mathrm{C}_{18} / \mathrm{SO}_{3} \mathrm{H}\right] @ \mathrm{SiO}_{2} \mathrm{NPs}$. This structure may also be regarded as $\left[\mathrm{C}_{18} / \mathrm{SO}_{3} \mathrm{H}\right] @ \mathrm{SiO}_{2}$ supramolecular host networks in which the introduction of $\left[\mathrm{C}_{12}\right]_{3}\left[\mathrm{PW}_{12} \mathrm{O}_{40}\right]$ NPs (guests) occurs with the formation of inclusion-type compounds. At this stage, to explain the Pickering stabilization by both NPs, we can suggest a mechanism based on specific interactions between the $\left[\mathrm{C}_{12}\right]_{3}\left[\mathrm{PW}_{12} \mathrm{O}_{40}\right]$ and $\left[\mathrm{C}_{18} / \mathrm{SO}_{3} \mathrm{H}\right] @ \mathrm{SiO}_{2} \mathrm{NPs}$ leading to the formation of aggregates at the oil/water interface. This assumption is supported by the freeze-fracture cryo-SEM micrographs of the emulsion (Fig. 4).

Next, the emulsion stability was examined as a function of storage time at $60{ }^{\circ} \mathrm{C}$ for the $\left[\mathrm{C}_{n} / \mathrm{SO}_{3} \mathrm{H}\right] @ \mathrm{SiO}_{2} \mathrm{NPs}$ either alone or combined with $\left[\mathrm{C}_{12}\right]_{3}\left[\mathrm{PW}_{12} \mathrm{O}_{40}\right]$. As depicted in Fig. 5, the emulsion stability for the NPs alone increases in the order $\left[\mathrm{C}_{8} /\right.$ $\left.\mathrm{SO}_{3} \mathrm{H}\right] @ \mathrm{SiO}_{2}<\left[\mathrm{C}_{12}\right]_{3}\left[\mathrm{PW}_{12} \mathrm{O}_{40}\right]<\left[\mathrm{C}_{18} / \mathrm{SO}_{3} \mathrm{H}\right] @ \mathrm{SiO}_{2}$.

In order to identify the possible destabilization mechanisms, we also performed a series of multiple light scattering experiments coupled with vertical scanning (Fig. 6).

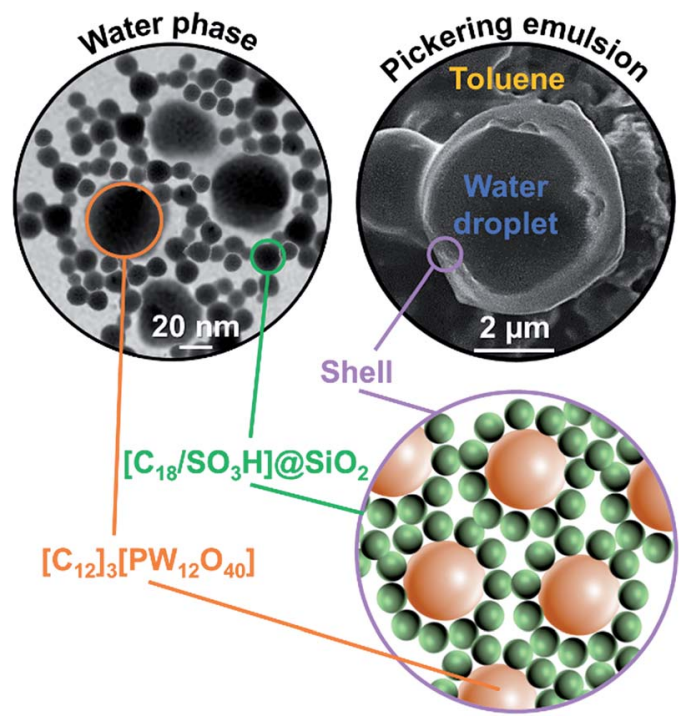

Fig. 4 TEM micrograph of $\left[\mathrm{C}_{12}\right]_{3}\left[\mathrm{PW}_{12} \mathrm{O}_{40}\right]$ and $\left[\mathrm{C}_{18} / \mathrm{SO}_{3} \mathrm{H}\right] \mathrm{aSiO}{ }_{2} \mathrm{NP}$ mixture (3.6 wt\%, $\phi=0.5)$ after dispersion in water (left) and cryo-SEM micrograph of water/toluene emulsions $(1 / 1 \mathrm{v} / \mathrm{v})$ of $\left[\mathrm{C}_{18} / \mathrm{SO}_{3} \mathrm{H}\right] \mathrm{aSiO}_{2} /$ $\left[\mathrm{C}_{12}\right]_{3}\left[\mathrm{PW}_{12} \mathrm{O}_{40}\right]$ mixtures (3.6 wt\%, $\phi=0.5,11500 \mathrm{rpm}$, right). The inset shows a representation of the NPs in water and at the surface droplets.

The time-evolution of backscattering is characteristic of a sedimentation process, leading to the clarification of the continuous phase (toluene). Indeed, the backscattering level increases at the bottom due to a higher droplet concentration in this part of the sample, thus suggesting a sedimentation phenomenon (black arrow). In contrast, when looking at the

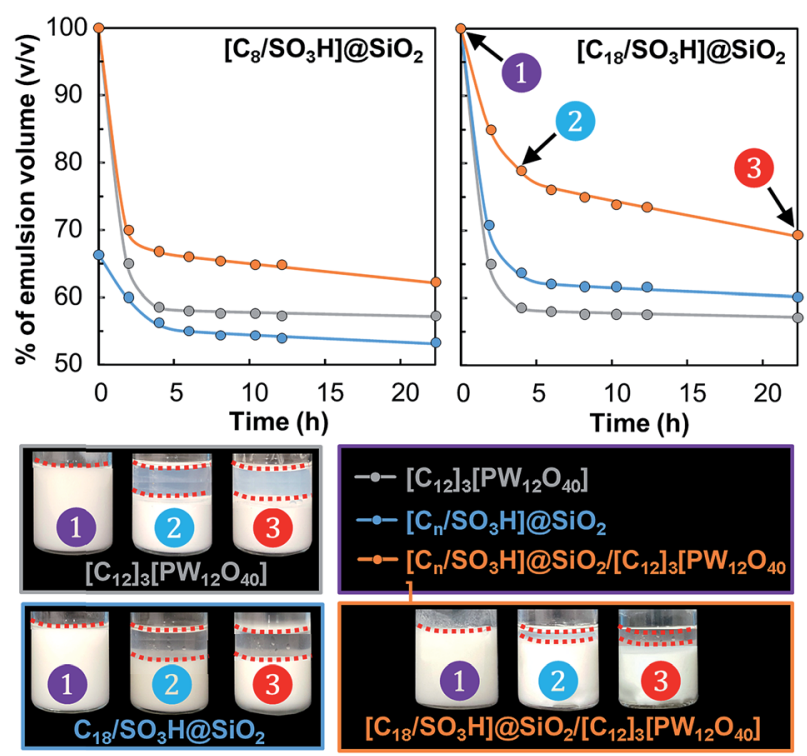

Fig. 5 Evolution of the emulsion volume fraction (S.D. $=2 \%$ ) as a function of the storage time at $60{ }^{\circ} \mathrm{C}$ for water/toluene emulsions $(1 / 1 \mathrm{v} / \mathrm{v})$ stabilized by $\left[\mathrm{C}_{n} / \mathrm{SO}_{3} \mathrm{H}\right] \mathrm{aSiO}_{2}$ and $\left[\mathrm{C}_{12}\right]_{3}\left[\mathrm{PW}_{12} \mathrm{O}_{40}\right] \mathrm{NPs}$ or a mixture of both NPs (3.6 wt\%, $\phi=0.5,11500 \mathrm{rpm})$. The insets show the W/O emulsions stabilized by $\left[\mathrm{C}_{18} / \mathrm{SO}_{3} \mathrm{H}\right] \mathrm{aSiO}_{2}$ and/or $\left[\mathrm{C}_{12}\right]_{3}\left[\mathrm{PW}_{12} \mathrm{O}_{40}\right] \mathrm{NPs}$. 
top of the cell, we observe a decrease of the backscattering, which is due to the clarification (red arrow). Moreover, clarification and sedimentation fronts were clearly devised (purple and green arrows, respectively). This sedimentation process can be explained by the self-aggregation of both NPs. Indeed, van der Waals attraction forces, observed in aqueous solution, also operate between NPs located at the droplet surface, leading the droplets to get closer. As the gravitational force exceeds the thermal motion of the connected droplets (Brownian motion), a concentration gradient builds up in the system. As a result, larger droplets move rapidly to the bottom of the sample (their density is higher than that of the medium). At these conditions, the connected droplets form a close-packed array at the bottom of the system, with the remainder of the volume being occupied by the continuous phase. However, sedimentation does not favor ultimate coalescence because of the NP dense film located at the oil/ water interface: the measured droplet size of the emulsion does not vary with time. As depicted in Fig. 5 and 6, droplet sedimentation occurs within the first hours after emulsification. Moreover, sedimentation stops more efficiently when hydrophobic NPs are used, reflecting stronger interactions between the NPs and the oil molecules than those between the NPs, leading to higher droplet stability. The resistance to sedimentation is higher for the mixed NP systems. This confirms the strong attractive interaction between both NPs due to the sponge-like structure of $\left[\mathrm{C}_{12}\right]_{3}\left[\mathrm{PW}_{12} \mathrm{O}_{40}\right]$ NPs, where some alkyl chains of $\left[\mathrm{C}_{n} / \mathrm{SO}_{3} \mathrm{H}\right] @ \mathrm{SiO}_{2}$ can be accommodated. ${ }^{6}$ This behaviour is more distinct for $\left[\mathrm{C}_{18} / \mathrm{SO}_{3} \mathrm{H}\right] @ \mathrm{SiO}_{2} \mathrm{NPs}$ due to the large "hydrophobic" contact area between the alkyl chains after their penetration inside $\left[\mathrm{C}_{12}\right]_{3}\left[\mathrm{PW}_{12} \mathrm{O}_{40}\right] \mathrm{NPs}^{6}$ Therefore, these emulsions show stability during the reaction time and can be destabilized on demand by centrifugation (4000 rpm, $20 \mathrm{~min}$ ). In addition, droplet sedimentation, which is not a destructive and irreversible process, can be readily avoided during the reaction by stirring at $500 \mathrm{rpm}$ (see below).

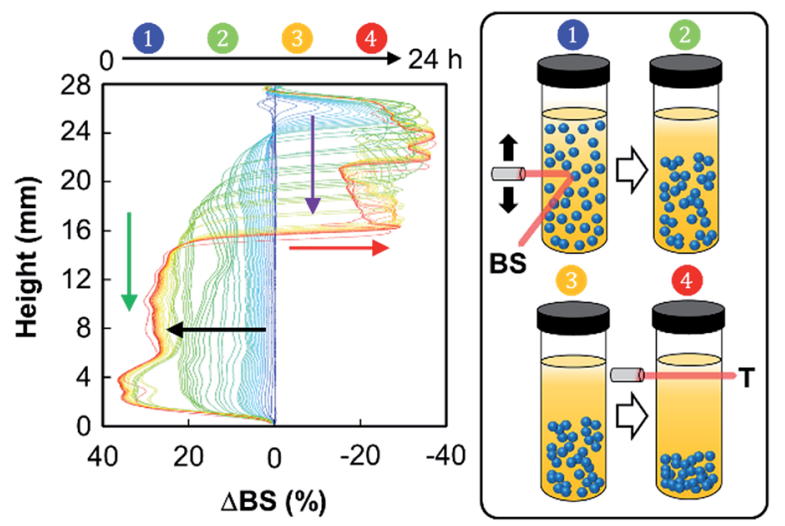

Fig. 6 Variation of backscattering at $60^{\circ} \mathrm{C}(\Delta \mathrm{BS})$ versus sample height and time of $\left[\mathrm{C}_{18} / \mathrm{SO}_{3} \mathrm{H}\right]\left(\mathrm{CSiO}_{2} /\left[\mathrm{C}_{12}\right]_{3}\left[\mathrm{PW}_{12} \mathrm{O}_{40}\right]\right.$ mixtures $(3.6 \mathrm{wt} \%, \phi=$ $0.5,11500 \mathrm{rpm}$ ) from 0 (blue curve) to $24 \mathrm{~h}$ (red curve). The inset shows a representation of the time-evolution of the clarification/ sedimentation process ( $\mathrm{T}=$ transmitted light and $\mathrm{BS}=$ backscattered light) of the emulsion.
The water/toluene emulsions stabilized by $\left[\mathrm{C}_{18} / \mathrm{SO}_{3} \mathrm{H}\right]$ @ $\mathrm{SiO}_{2}$ and $\left[\mathrm{C}_{12}\right]_{3}\left[\mathrm{PW}_{12} \mathrm{O}_{40}\right]$ NPs were further inspected directly (without use of a replica) by cryo-SEM (Fig. 7). The freezefracture of the emulsions varies in appearance depending on the fracture plane and the structural heterogeneity of the droplets. As the frozen droplets are randomly located, freezefracture was performed in non-mid planes, resulting in a difficult measure of the droplet. However, cross-fractured droplets (where the plane of the fracture passes through the mid plane) reveal a size compatible with the mean droplet diameter measured by optical microscopy. It is noteworthy that $\left[\mathrm{C}_{12}\right]_{3}\left[\mathrm{PW}_{12} \mathrm{O}_{40}\right]$ alone can generate crystalline organizations in the interfacial layer (Fig. 7A and $\mathrm{A}^{\prime}$ ) driven solely by the self-assembly of $\left[\mathrm{C}_{12}\right]_{3}\left[\mathrm{PW}_{12} \mathrm{O}_{40}\right]$ NPs at long scale. However, for the single $\left[\mathrm{C}_{12}\right]_{3}\left[\mathrm{PW}_{12} \mathrm{O}_{40}\right]$ NPs, electrostatic forces and/or steric effects are not relevant due to the negative $\zeta$-potential and monodisperse size distribution (Table 1). The self-assembly of $\left[\mathrm{C}_{12}\right]_{3}\left[\mathrm{PW}_{12} \mathrm{O}_{40}\right]$ NPs relies on recognition events, leading to a supracolloidal interface governed by hydrophobic forces. Indeed, toluene penetration inside $\left[\mathrm{C}_{12}\right]_{3}\left[\mathrm{PW}_{12} \mathrm{O}_{40}\right]$ NPs can lead to the release of alkyl chains, allowing their interlocking. ${ }^{6}$ In the case of $\left[\mathrm{C}_{18} / \mathrm{SO}_{3} \mathrm{H}\right] @ \mathrm{SiO}_{2}$ NPs, interlocking between NPs probably exists, but without encompassing a large or well-ordered organization. For NP mixtures, the presence of $\left[\mathrm{C}_{18} / \mathrm{SO}_{3} \mathrm{H}\right] @ \mathrm{SiO}_{2}$, even at a very low mass fraction $(\phi=0.05)$, decreases the thickness of the NP layer. Therefore, the attractive interaction between both NPs is larger than the self-assembly of $\left[\mathrm{C}_{12}\right]_{3}\left[\mathrm{PW}_{12} \mathrm{O}_{40}\right] \mathrm{NPs}$ in colloidal crystals.

With these results in hand, we explored the effect of catalytic properties of $\left[\mathrm{C}_{12}\right]_{3}\left[\mathrm{PW}_{12} \mathrm{O}_{40}\right]$ and $\left[\mathrm{C}_{n} / \mathrm{SO}_{3} \mathrm{H}\right] @ \mathrm{SiO}_{2} \mathrm{NPs}$ on the oxidative cleavage of cyclohexene oxide (Table 2). The tests were carried out at $80{ }^{\circ} \mathrm{C}$ with a 50/50 mass ratio of $\left[\mathrm{C}_{18} / \mathrm{SO}_{3} \mathrm{H}\right] @ \mathrm{SiO}_{2}$ and $\left[\mathrm{C}_{12}\right]_{3}\left[\mathrm{PW}_{12} \mathrm{O}_{40}\right]$ NPs. The diacid/diol ratio was used to assess whether the hydrolysis or oxidation steps are of significance in the mixed emulsions. To assess the influence of each catalyst on the reaction, a first series of experiments was

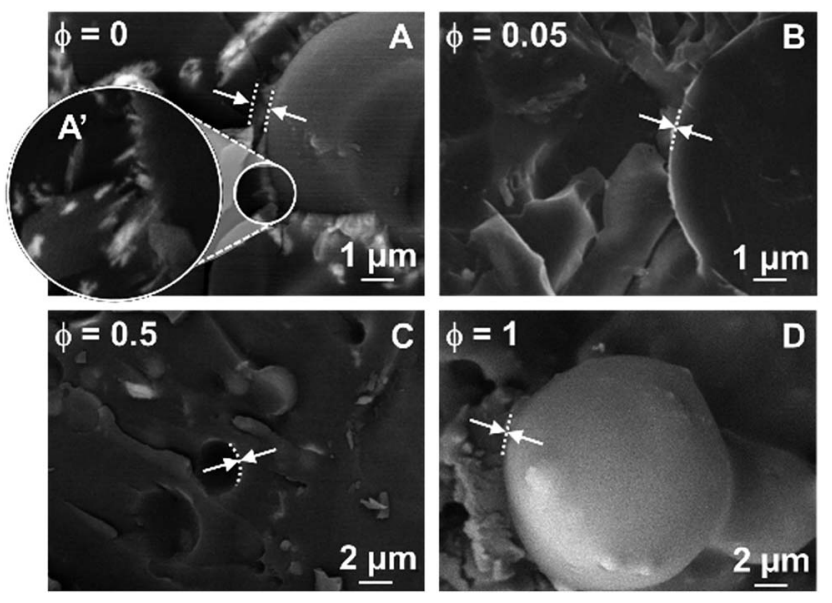

Fig. 7 Cryo-SEM micrographs of water/toluene emulsions $(1 / 1 \mathrm{v} / \mathrm{v})$ as a function of the $\left[\mathrm{C}_{18} / \mathrm{SO}_{3} \mathrm{H}\right]$ @ $\mathrm{SiO}_{2}$ mass fraction $(\phi)$ for $\left[\mathrm{C}_{18} / \mathrm{SO}_{3} \mathrm{H}\right]$ $\mathrm{aSiO}_{2} /\left[\mathrm{C}_{12}\right]_{3}\left[\mathrm{PW}_{12} \mathrm{O}_{40}\right]$ mixtures $(3.6 \mathrm{wt} \%, 11500 \mathrm{rpm})$. The white arrows and the dashed lines indicate the thickness of the NPs layer. 
performed either without (entry 1) or with the single NPs (entries 2 and 3). For the catalyst-free reaction, a nearly quantitative cyclohexene conversion (>99\%) is observed after $12 \mathrm{~h}$ along with a very low adipic acid selectivity (6\%) and a diacid/ diol ratio of 0.1 (entry 1). These values are typical of uncatalyzed epoxide ring opening in aqueous solution..$^{25}$ This observation points out that the overall reaction rate is clearly controlled by the rate of the oxidation steps. The above hypothesis is fully supported by a second control experiment using $\left[\mathrm{C}_{18} / \mathrm{SO}_{3} \mathrm{H}\right] @ \mathrm{SiO}_{2}$ as the catalyst (Table 2, entry 2). A 2-fold increase of the adipic acid selectivity is obtained under the same reaction conditions, which can be attributed to a faster hydrolysis of adipic anhydride into adipic acid. The diacid/diol ratio remains identical to the value measured without catalyst (i.e. 0.1 ), confirming that the oxidation reactions are not affected by the $\left[\mathrm{C}_{18} / \mathrm{SO}_{3} \mathrm{H}\right] @ \mathrm{SiO}_{2}$ catalyst. We next performed the oxidative cleavage of cyclohexene oxide with the single $\left[\mathrm{C}_{12}\right]_{3}\left[\mathrm{PW}_{12} \mathrm{O}_{40}\right]$ NPs (entry 3 ). The adipic acid selectivity after $12 \mathrm{~h}$ is 10 -fold higher than without catalyst, while the diacid/diol ratio increases to 2.0. This clearly indicates that $\left[\mathrm{C}_{12}\right]_{3}\left[\mathrm{PW}_{12} \mathrm{O}_{40}\right]$ sitting at the $\mathrm{W} / \mathrm{O}$ interface can lower the activation energy of the rate-limiting oxidation steps, resulting in a higher reaction rate. The combination of $\left[\mathrm{C}_{18} / \mathrm{SO}_{3} \mathrm{H}\right] @ \mathrm{SiO}_{2}$ and $\left[\mathrm{C}_{12}\right]_{3}\left[\mathrm{PW}_{12} \mathrm{O}_{40}\right]$ NPs acts as an efficient promoter for adipic acid production. Indeed, the selectivity after $12 \mathrm{~h}$ is almost 15 times higher than that for the control experiment without catalyst (Table 2, entries 1 and 4), resulting in an isolated yield of $94 \%$ and a diacid/diol ratio about 23 . This high activity results not only from the microstructured reaction medium, but also from the synergy between both NPs. It is noteworthy that cyclohexene oxide was quantitatively converted into the diol after $30 \mathrm{~min}$, this step being faster than the following oxidation steps (see ESI, Fig. S6†). To discern between mass transfer and intrinsic kinetics, the activation energy was determined from the Arrhenius plot, showing a value of $74.5 \mathrm{~kJ} \mathrm{~mol}^{-1}$ (see ESI, Fig. S7†), which is typical of diffusion-free tungsten-catalyzed

Table 2 Oxidative cleavage of cyclohexene oxide in water/oil (toluene, $\mathrm{T}$, dibutyl ether, DBE and heptane, $\mathrm{H})^{a}$

\begin{tabular}{llllll}
\hline$n^{\circ}$ & Oil & {$[\mathrm{X}]_{3}\left[\mathrm{PW}_{12} \mathrm{O}_{40}\right]$} & {$\left[\mathrm{C}_{n} / \mathrm{SO}_{3} \mathrm{H}\right] @ \mathrm{SiO}_{2}$} & $\mathrm{~S}^{b} \%$ & Diacid/diol $^{c}$ \\
\hline 1 & $\mathrm{~T}$ & - & - & 6 & 0.1 \\
2 & $\mathrm{~T}$ & - & {$\left[\mathrm{C}_{18} / \mathrm{SO}_{3} \mathrm{H}\right] @ \mathrm{SiO}_{2}$} & 12 & 0.1 \\
3 & $\mathrm{~T}$ & {$\left[\mathrm{C}_{12}\right]_{3}\left[\mathrm{PW}_{12} \mathrm{O}_{40}\right]$} & - & 63 & 2.0 \\
4 & $\mathrm{~T}$ & {$\left[\mathrm{C}_{12}\right]_{3}\left[\mathrm{PW}_{12} \mathrm{O}_{40}\right]$} & {$\left[\mathrm{C}_{18} / \mathrm{SO}_{3} \mathrm{H}\right] @ \mathrm{SiO}_{2}$} & 94 & 23.3 \\
$5^{d}$ & $\mathrm{~T}$ & {$[\mathrm{Na}]_{3}\left[\mathrm{PW}_{12} \mathrm{O}_{40}\right]$} & {$\left[\mathrm{C}_{18} / \mathrm{SO}_{3} \mathrm{H}\right] @ \mathrm{SiO}_{2}$} & 25 & 0.7 \\
$6^{e}$ & $\mathrm{~T}$ & {$\left[\mathrm{C}_{12}\right]_{3}\left[\mathrm{PW}_{12} \mathrm{O}_{40}\right]$} & $\mathrm{H}_{2} \mathrm{SO}_{4}$ & 75 & 3.9 \\
$7^{f}$ & $\mathrm{~T}$ & {$\left[\mathrm{C}_{12}\right]_{3}\left[\mathrm{PW}_{12} \mathrm{O}_{40}\right]$} & {$\left[\mathrm{C}_{18} / \mathrm{SO}_{3} \mathrm{H}\right] @ \mathrm{SiO}_{2}$} & 48 & 1.2 \\
8 & $\mathrm{DBE}$ & {$\left[\mathrm{C}_{12}\right]_{3}\left[\mathrm{PW}_{12} \mathrm{O}_{40}\right]$} & {$\left[\mathrm{C}_{18} / \mathrm{SO}_{3} \mathrm{H}\right] @ \mathrm{SiO}_{2}$} & 52 & 1.0 \\
9 & $\mathrm{H}$ & {$\left[\mathrm{C}_{12}\right]_{3}\left[\mathrm{PW}_{12} \mathrm{O}_{40}\right]$} & {$\left[\mathrm{C}_{18} / \mathrm{SO}_{3} \mathrm{H}\right] @ \mathrm{SiO}_{2}$} & 19 & 0.3 \\
10 & $\mathrm{~T}$ & {$\left[\mathrm{C}_{12}\right]_{3}\left[\mathrm{PW}_{12} \mathrm{O}_{40}\right]$} & {$\left[\mathrm{C}_{8} / \mathrm{SO}_{3} \mathrm{H}\right] @ \mathrm{SiO}_{2}$} & 92 & 18.2
\end{tabular}

${ }^{a}\left[\mathrm{C}_{n} / \mathrm{SO}_{3} \mathrm{H}\right] @ \mathrm{SiO}_{2}=50 \mathrm{mg},[\mathrm{X}]_{3}\left[\mathrm{PW}_{12} \mathrm{O}_{40}\right]=50 \mathrm{mg}$, toluene $=1.5 \mathrm{~mL}$, water $=1.5 \mathrm{~mL}$, cyclohexene oxide $=1.5 \mathrm{mmol}, \mathrm{H}_{2} \mathrm{O}_{2}=5.25 \mathrm{mmol}$, $80{ }^{\circ} \mathrm{C}, 500 \mathrm{rpm}, 12 \mathrm{~h}$. Conv. of substrate $>99 \% .{ }^{b}$ (Mol. of adipic acid)/ (mol. of converted cyclohexene oxide) $\times 100$. The side products were mainly glutaric acid, succinic acid, 2-hydroxycyclohexanone and 7 hydroxyoxepan-2-one. ${ }^{c}$ Ratio of adipic acid to 1,2-cyclohexanediol. ${ }^{d}[\mathrm{Na}]_{3}\left[\mathrm{PW}_{12} \mathrm{O}_{40}\right]=15 \mu \mathrm{mol} .{ }^{e} \mathrm{H}_{2} \mathrm{SO}_{4}=9.5 \times 10^{-3} \mathrm{mmol}^{.}{ }^{f}\left[\mathrm{C}_{18} / \mathrm{SO}_{3} \mathrm{H}\right]$ (a) $\mathrm{SiO}_{2}=25 \mathrm{mg},\left[\mathrm{C}_{12}\right]_{3}\left[\mathrm{PW}_{12} \mathrm{O}_{40}\right]=25 \mathrm{mg}$. oxidation reactions (range of $50-90 \mathrm{~kJ} \mathrm{~mol}^{-1}$ ). ${ }^{26-28}$ Consequently the reaction rate does not appear to be affected by mass transfer due to the large interfacial surface area generated, the reaction occurring in the interfacial layer. The recycling of the catalytic system was then investigated: the already used emulsified reaction medium was centrifuged (4000 rpm for $20 \mathrm{~min}$ ). The mixed catalytic NPs were filtered, washed with ethanol $(3 \times$ $5 \mathrm{~mL}$ ), and dried. A new batch of fresh cyclohexene oxide (1.5 $\mathrm{mmol})$ in toluene $(1.5 \mathrm{~mL})$, and $\mathrm{H}_{2} \mathrm{O}_{2}(5.25 \mathrm{mmol})$ in water $(1.5$ $\mathrm{mL}$ ) were added to the NPs. The reaction proceeds without any loss of activity (i.e. conversion) and selectivity after five consecutive recycles. Therefore, catalytic and amphiphilic NPs capable of stabilizing Pickering emulsions improve: (i) the performance of the catalytic systems due to the presence of NPs at the interface leading to a huge interfacial area and promoting the mass transfer, (ii) phase separation, and (iii) the ecological aspect of the process.

To provide further evidence of the synergy between the different catalytic NPs, a series of control experiments were performed under the same reaction conditions by replacing the $\left[\mathrm{C}_{18} / \mathrm{SO}_{3} \mathrm{H}\right] @ \mathrm{SiO}_{2}$ and $\left[\mathrm{C}_{12}\right]_{3}\left[\mathrm{PW}_{12} \mathrm{O}_{40}\right] \mathrm{NPs}$ by $\left[\mathrm{C}_{18} / \mathrm{SO}_{3} \mathrm{H}\right] @ \mathrm{SiO}_{2}$ and the water-soluble $[\mathrm{Na}]_{3}\left[\mathrm{PW}_{12} \mathrm{O}_{40}\right]$, or by $\left[\mathrm{C}_{12}\right]_{3}\left[\mathrm{PW}_{12} \mathrm{O}_{40}\right] \mathrm{NPs}$ and homogeneous $\mathrm{H}_{2} \mathrm{SO}_{4}$ (entries 5 and 6). For both catalytic systems, the presence of a homogeneous catalyst ( $[\mathrm{Na}]_{3}\left[\mathrm{PW}_{12} \mathrm{O}_{40}\right]$ or $\mathrm{H}_{2} \mathrm{SO}_{4}$ ) instead of the two surface-active NPs does not affect the substrate conversion (>99\%), but discourages diacid formation (compare entries 4, 5 and 6). These results clearly indicate that the presence of $\left[\mathrm{C}_{18} / \mathrm{SO}_{3} \mathrm{H}\right] @ \mathrm{SiO}_{2}$ and $\left[\mathrm{C}_{12}\right]_{3}\left[\mathrm{PW}_{12} \mathrm{O}_{40}\right]$ NPs at the W/O interface is essential to achieve high adipic acid selectivity. As both NPs interact to provide a nanostructured catalytic Pickering interface, in which the water/oil (W/O) interfacial area hugely favors mass transfer and catalyzes the various hydrolysis and oxidation steps (see Fig. 2), the overall reaction rate is enhanced, allowing the formation of the desired product (diacid) after $12 \mathrm{~h}$. Next, the effect of the catalyst amount on the catalytic activity was investigated (entry 7). As the catalyst amount was divided by 2 , an unstable emulsion was obtained. At these conditions, the surface-active NPs provide a high substrate conversion after $12 \mathrm{~h}$, but the diacid selectivity is affected. All these observations support an interfacial catalytic mechanism, where the coadsorption of both catalysts at the W/O interface is essential for producing adipic acid. As a consequence, there is a close relation between the structure of both NPs (i.e. the presence and spatial distance of the hydrophobic binding sites) and the catalytic performance of the resulting emulsions.

Additional oxidative cleavage experiments were performed using either $n$-heptane or di-n-butyl ether as solvents. Unlike toluene, the activity, selectivity and diacid/diol ratio decrease for both solvents (entries 8 and 9). We can reasonably assume that these linear solvents act as competitive inhibitors of the porous $\left[\mathrm{C}_{12}\right]_{3}\left[\mathrm{PW}_{12} \mathrm{O}_{40}\right]$ NPs. The binding of $n$-heptane and di- $n$ butyl ether with $\left[\mathrm{C}_{12}\right]_{3}\left[\mathrm{PW}_{12} \mathrm{O}_{40}\right]$ NPs is expected to reduce the $\left[\mathrm{C}_{18} / \mathrm{SO}_{3} \mathrm{H}\right] @ \mathrm{SiO}_{2} /\left[\mathrm{C}_{12}\right]_{3}\left[\mathrm{PW}_{12} \mathrm{O}_{40}\right]$ interaction. The results indicate that the most hydrophobic solvent ( $n$-heptane) provides a stronger inhibitory effect due to easier penetration into the $\left[\mathrm{C}_{12}\right]_{3}\left[\mathrm{PW}_{12} \mathrm{O}_{40}\right] \mathrm{NPs}$ in agreement with the eluotropic series. ${ }^{29}$ 
To gain more insight into the attractive interactions between the NPs, an experiment was performed for the $\left[\mathrm{C}_{8} / \mathrm{SO}_{3} \mathrm{H}\right] @ \mathrm{SiO}_{2} /$ $\left[\mathrm{C}_{12}\right]_{3}\left[\mathrm{PW}_{12} \mathrm{O}_{40}\right]$ system (entry 10). Even if the conversion remains almost quantitative, the adipic acid selectivity is slightly lower than for the $\left[\mathrm{C}_{18} / \mathrm{SO}_{3} \mathrm{H}\right] @ \mathrm{SiO}_{2} /\left[\mathrm{C}_{12}\right]_{3}\left[\mathrm{PW}_{12} \mathrm{O}_{40}\right]$ system. Concomitantly, the diacid/diol ratio drops from 23 to 18 (entries 4 and 10). Again, we can reasonably argue that this effect is correlated with the chain length of the $\left[\mathrm{C}_{n} / \mathrm{SO}_{3} \mathrm{H}\right]$ (a) $\mathrm{SiO}_{2} \mathrm{NPs}$. Indeed, the strength of London forces is directly proportional to the "hydrophobic" contact area after penetration, increasing the cohesion of the catalytic interface.

On the basis of literature data, to obtain selectively adipic acid ( $>70 \%)$ from the oxidative cleavage of cyclohexene and/or its derivatives with $\mathrm{W}$-based catalysts under mild reaction conditions $\left(<100{ }^{\circ} \mathrm{C}\right.$ and $\left.>600 \mathrm{rpm}\right)$ and acceptable time $(<24 \mathrm{~h})$, several elegant approaches have been explored in the last two decades including organic acids, ${ }^{30}$ phase transfer catalysts, ${ }^{31-33}$ catalytic surfactants, ${ }^{34}$ catalytic ionic liquids ${ }^{35}$ and supported catalysts. $^{36,37}$ Although all these systems solve the phase incompatibility issue, they suffer from one or more of the following drawbacks: (i) catalyst leaching, (ii) complex phase separation, especially in the presence of surfactants or organic acids, (iii) requirement of washing and neutralization of the reaction medium (systems using homogeneous acids), which generates waste water treatment problems, and/or (iv) sometimes there is a need for a co-solvent especially with supported catalysts (e.g., acetonitrile). All these issues can be solved here as the PIC system allows reaction completion (after $12 \mathrm{~h}$ ) under mild conditions $\left(80^{\circ} \mathrm{C}\right.$ and $\left.500 \mathrm{rpm}\right)$ without co-solvents. Products and catalysts are readily separated by simple centrifugation. Even if silica NPs require synthetic surface modification, the catalytic $\left[\mathrm{C}_{n} / \mathrm{SO}_{3} \mathrm{H}\right] @ \mathrm{SiO}_{2} /\left[\mathrm{C}_{12}\right]_{3}\left[\mathrm{PW}_{12} \mathrm{O}_{40}\right]$ system is efficient and globally eco-friendly because it minimizes the use of organic solvents (or co-solvents) and can be easily re-used without waste generation.

Finally, to extend the scope of the system, the oxidative cleavage of other cycloalkene oxides (i.e. cycloheptene, cyclooctene, 1-methylcyclohexene, and 4-methylcyclohexene) was carried out at the same reaction conditions (Table 3 ). To allow a proper comparison of the catalytic performance of the different substrates, the reaction time was set at $12 \mathrm{~h}$. As depicted in Table 3, all cycloalkene oxides were quasiquantitatively converted (conv. $\geq 99 \%$ ) to their corresponding carboxylic acids with an isolated yield $\geq 69 \%$. As the oxidation of alkene oxides to carboxylic acids occurs via the formation of diol intermediates, which constitute the major side product based on ${ }^{1} \mathrm{H}$ NMR spectroscopic analysis of the crude reaction mixture, the overall reaction rate is clearly controlled by the rate of the oxidation steps (see Fig. 2). Consequently, the susceptibility of the cycloalkene oxides to oxidation steps is as follows: 1-methylcyclohexene $<$ 4-methylcyclohexene $<$ cyclooctene $<$ cycloheptene $<$ cyclohexene oxides. However, it is noteworthy that all cycloalkene oxides can be oxidized to their corresponding acids with a yield $\geq 90 \%$ after $24 \mathrm{~h}$. Therefore, the combination of $\left[\mathrm{C}_{18} / \mathrm{SO}_{3} \mathrm{H}\right] @ \mathrm{SiO}_{2}$ and $\left[\mathrm{C}_{12}\right]_{3}\left[\mathrm{PW}_{12} \mathrm{O}_{40}\right] \mathrm{NPs}$ acts as an efficient promoter for acid production at acceptable reaction times and facilitates the recycling of the catalytic system.
Table 3 Oxidative cleavage of cycloalkene oxides in water/toluene Pickering emulsion stabilized by $\left[\mathrm{C}_{18} / \mathrm{SO}_{3} \mathrm{H}\right] \mathrm{aSiO}_{2}$ and $\left[\mathrm{C}_{12}\right]_{3}\left[\mathrm{PW}_{12} \mathrm{O}_{40}\right]$ NPs at $80^{\circ} \mathrm{C}^{a}$

Substrate

\section{Conclusions}

Pickering emulsions could be designed and stabilized by two catalytic amphiphilic NPs using the colloidal tectonics approach. The porous $\left[\mathrm{C}_{12}\right]_{3}\left[\mathrm{PW}_{12} \mathrm{O}_{40}\right]$ NPs allow the accommodation of $\mathrm{C}_{18}$ chains belonging to $\left[\mathrm{C}_{18} / \mathrm{SO}_{3} \mathrm{H}\right] @ \mathrm{SiO}_{2}$, resulting in their interlocking. In the presence of a W/O biphasic system, these attractive interactions act as elastic "springs" in the interfacial layer, conditioning the droplet size and the emulsion stability. At optimal conditions, such systems are efficient for the conversion of cycloalkene oxides into diacids combining the benefits of supramolecular chemistry (flexible, versatile and highly dynamic self-assembly systems) with homogeneous (high activity and selectivity) and heterogeneous catalysis (simple phase separation and catalyst reuse). This novel approach opens interesting and unprecedented perspectives and foreshadows the advent of predictable colloidal selfassembly methodologies for catalysis. Work is under way to extend these systems to other tandem reactions.

\section{Conflicts of interest}

There are no conflicts to declare.

\section{Acknowledgements}

This project was funded by Solvay via a CIFRE grant. Cryo-SEM pictures have been taken at Placamat. Chevreul Institute (FR 2638), Ministère de l'Enseignement Supérieur et de la 
Recherche, Région Nord - Pas de Calais and Fonds Européen de Développement Régional (FEDER) are acknowledged for supporting and funding partially this work.

\section{References}

1 M. Pera-Titus, L. Leclercq, J.-M. Clacens, F. De Campo and V. Nardello-Rataj, Angew. Chem., Int. Ed., 2015, 54, 2006.

2 L. Leclercq, A. Mouret, A. Proust, V. Schmitt, P. Bauduin, J.-M. Aubry and V. Nardello-Rataj, Chem.-Eur. J., 2012, 18, 14352.

3 Z. Fan, A. Tay, M. Pera-Titus, W.-J. Zhou, S. Benhabbari, X. Feng, G. Malcouronne, L. Bonneviot, F. De Campo, L. Wang and J.-M. Clacens, J. Colloid Interface Sci., 2014, 427, 80 .

4 Y. Xie, M. Sun, Y. Shen, H. Li, G. Lv, Z. Cai, C. Yang, G. A. A. Ali, F. Wang and X. Zhang, RSC Adv. , 2016, 6, 101808.

5 B. Yang, L. Leclercq, J.-M. Clacens and V. Nardello-Rataj, Green Chem., 2017, 19, 4552.

6 L. Leclercq, A. Mouret, P. Bauduin and V. Nardello-Rataj, Langmuir, 2014, 30, 5386.

7 L. Leclercq, A. Mouret, S. Renaudineau, V. Schmitt, A. Proust and V. Nardello-Rataj, J. Phys. Chem. B, 2015, 119, 6326.

8 L. Leclercq, Front. Chem., 2018, 6, 168.

9 H. Ma and L. L. Dai, Langmuir, 2011, 27, 508.

10 L. L. Dai, S. Tarimala, C.-Y. Wu, S. Guttula and J. Wu, Scanning, 2008, 30, 87.

11 T. Nallamilli, E. Mani and M. G. Basavaraj, Langmuir, 2014, 30, 9336.

12 T. R. Nallamilli, B. P. Binks, E. Mani and M. G. Basavaraj, Langmuir, 2015, 31, 11200.

13 S. D. C. Pushpam, M. G. Basavaraj and E. Mani, Phys. Rev. E: Stat., Nonlinear, Soft Matter Phys., 2015, 92, 052314.

14 S. Frasch-Melnik, I. N. Norton and F. Spyropoulos, J. Food Eng., 2010, 98, 437.

15 D. Miller, E.-M. Wiener, A. Turowski, C. Thunig and H. Hoffmann, Colloids Surf., A, 1999, 152, 155.

16 R. C. Pasquali, M. P. Taurozzi, N. Sacco and C. Bregni, Lat. Am. J. Pharm., 2008, 27, 839.
17 F. C. Wang, F. Peyrone and A. G. Marangoni, Cryst. Growth Des., 2016, 16, 297.

18 S. Barg, B. P. Binks, H. Wang, D. Koch and G. Grathwohl, J. Porous Mater., 2012, 19, 859.

19 S. Wang, Y. He and Y. Zou, Particuology, 2010, 8, 390.

20 H. Xu, M. Lask, J. Kirkwood and G. Fuller, Langmuir, 2007, 23, 4837.

21 S. Crossley, J. Faria, M. Shen and D. E. Resasco, Science, 2010, 327, 68.

22 P. A. Zapata, J. Faria, M. P. Ruiz and D. E. Resasco, Top. Catal., 2012, 55, 38.

23 H. Ulrich, Raw Materials for Industrial Polymers, Hanser Publishers, Munich, 1988.

24 R. Noyori, M. Aoki and K. Sato, Chem. Commun., 2003, 1977.

25 Z. Wang, Y.-T. Cui, Z.-B. Xu and J. Qu, J. Org. Chem., 2008, 73, 2270 .

26 G. G. Allan and A. N. Neogi, J. Catal., 1976, 16, 197.

27 X. Jian and A. S. Hay, J. Polym. Sci., Part A: Polym. Chem., 1991, 29, 547.

28 K. Kamata, K. Yamaguchi and N. Mizuno, Chem.-Eur. J., 2004, 10, 4728.

29 S. H. Hansen, P. Helboe, U. Lund, Adsorption and partition chromatography in Separation methods, ed. Z.Deyl, Elsevier, Amsterdam, 1984, p. 169.

30 Y. Deng, Z. Ma, K. Wang and J. Chen, Green Chem., 1999, 1, 275.

31 K. Sato, M. Aoki and R. Noyori, Science, 1998, 281, 1646.

32 I. Vural-Gürsel, Q. Wang, T. Noël, V. Hessel and J. T. Tinge, Ind. Eng. Chem. Res., 2013, 52, 7827.

33 M. Shang, T. Noël, Y. I. Su and V. Hessel, Ind. Eng. Chem. Res., 2016, 55, 2669.

34 W. Zhu, H. Li, X. He, Q. Zhang, H. Shu and Y. Yan, Catal. Commun., 2008, 9, 551.

35 M. Vafaeezadeh and M. M. Hashemi, Chem. Eng. J., 2013, 221, 254.

36 M. Vafaeezadeh and M. M. Hashemi, Catal. Commun., 2014, 43, 169.

37 Z. Bohström, I. Rico-Lattes and K. Holmberg, Green Chem., 2010, 12, 1861. 